\title{
RECUPERAR A LÓGICA PÓETICA dA REVELAÇÃO: UMA CONTRIBUIÇÃO DO DIÁLOGO ENTRE TEOLOGIA E LITERATURA
}

RECOVER THE REVELATION'S POETIC LOGIC: A CONTRIBUTION FROM DIALOGUE BETWEEN THEOLOGY AND LITERATURE

\begin{abstract}
Alex Villas Boas ${ }^{(*)}$
\section{RESUMO}

O presente trabalho tem como objetivoa questão da busca de sentido da vida ou patodiceia inspirada na logoteoria de Viktor EmmilFrankl, (1905-1997) e o que a teologia tem a contribuir com a questão, verificando a sua capacidade de recepção sensível à problemática a partir da construção de uma teopatodiceia, no qual a teologia é vista como pergunta pelo sentido [logos] de Deus [Theós] na busca de sentido humana. Também é parte da proposta deste trabalho encontrar critérios para formular uma "lógica poética" como elemento formal adequado à proposta da teopatodiceia, resultando assim naquilo que chamamos de pensamento poético teológico, como forma de desvelamento de sentido, ou ainda, a apropriação existencial das fórmulas teológicas, por um empréstimo de pensamento da literatura.

Palavras Chave: Teologia e Literatura. Lógica Poética. Teopatodiceia. Teodiceia. Pensamento Poético Teológico.
\end{abstract}

\begin{abstract}
The aim of this present research is examine the relation between of the meaning of life other the pathodicy inspired by the Viktor Emmil Frankl's logotheory (1905-1997) and what contribution the theology can make about the question. The Theopathodicy theoretical construction results from the Theology's openness to issue understanding astheo-logy the query about the meaning [logos] of God [Theós], in the human search for meaning. Also, a second aim, as long as part of this proposed study, is find criteria to develop a literary reason, as far as formal element concerned to pathodicy, and consequently even the theopatodicy. And thus resulting in what we call poetic theological thought as a way of uncovering meaning, as well a proper way to make explicit the existential element of theological formulas for a loan thinking of Literature.
\end{abstract}

KEYWORD: Theology and Literature. Search for meaning. Theopathodicy. Poetic Theological Thought.

\footnotetext{
(*)Pós-Doutorado em Teologia pela PontificiaUniversità Gregoriana (Roma). Professor de Teologia na Pontifícia Universidade Católica de São Paulo (PUC SP). Coordenador do Grupo de Trabalho de Religião, Arte e Literatura da Sociedade Brasileira de Teologia e Ciências da Religião (SOTER). Editor da Revista Brasileira de Literaturas e Teologias - Teoliterária do Programa de Estudos Pós-Graduados em Teologia PUC SP (revistas.pucsp.br/teoliteraria). Agradecimento à Fundação de Amparo à Pesquisa do Estado do Rio de Janeiro - FAPERJ, pelo apoio a esta pesquisa. Email: avmariano@pucsp.br.
} 


\section{INTRODUÇÃO}

O presente artigo visa tratar daquilo que se pretende como pensamento poético teológico, a saber um modo peculiar de desvelamento de sentido do dadorevelacional, naquilo que se propõe como teopatodiceia, ou seja, como a hermenêutica da experiência de Deus (Theós) corrobora para um processo de subjetivação (pathos) responsável (diké), pessoal e social (VILLAS BOAS, 2012).

A proposta se insere dentro do âmbito de uma das possíveis contribuições do diálogo entre Teologia e Literatura. Com efeito, essa é uma das áreas que mais tem crescido no âmbito da Teologia e das Ciências da Religião, como constata uma pesquisa recente de Cantarela, chegando a quase 700 textos com cerca de 100 pesquisadores, no período de 1990 a 2013, entre artigos, livros, capítulos de livros, textos em anais de eventos, dissertações e teses sobre o assunto (2015: 107), sem contar a produção dos anos subsequentes, que continuou intensa nas instituições dedicadas a temática, consolidando deste modo uma área de pesquisa, com expressiva capilaridade. Atualmente, existem três Grupos de Pesquisa registrados no Conselho Nacional de Desenvolvimento Científico e Tecnológico (CNPq) ${ }^{1}$, a saber o Grupo de Pesquisa em Literatura, Religião e Teologia - LERTE, na Pontifícia Universidade Católica de São Paulo (PUC SP); liderado por Antônio Manzatto e Alex Villas Boas; o Grupo Teopoética de Estudos Comparados entre Teologia e Literatura na Universidade Federal de Santa Catarina (UFSC), liderado por Salma Ferraz e Antonio Carlos Magalhães (UEPA), e o recente Grupo de Hospitalidade, Alteridade e Feminino: Uma Transposição de Soleiras, liderado por Altamir Celio de Andrade e Maria Inês Castro Millen, do Centro de Ensino Superior de Juiz de Fora (CES/JF).

Contudo, há pesquisadores presentes em pelo menos dez estados da federação com alguma forma de aproximação do tema (AM, GO, MG, MS, PA, PE, PR, RJ, SC, SP). Do ponto de vista das associações há desde de 2008, o Grupo de Trabalho de Religião, Arte e Literatura na Sociedade Brasileira de Teologia e Ciências da Religião (SOTER), sendo um dos mais numerosos, e em 2015, teve início a Sessão de Trabalho de Diálogo entre Religião, Arte e Literatura na Associação Nacional de Pós-Graduação e Pesquisa em Teologia e Ciências da Religião (ANPTECRE). Vale ainda mencionar a grande participação de pesquisadores na ABRALIC - Associação Brasileira de Literatura Comparada. E neste ano de 2016 a Associação Latino Americana de Literaturas

\footnotetext{
${ }^{1}$ Ver http://dgp.cnpq.br/dgp/faces/consulta/consulta_parametrizada.jsf
} 
e Teologias (ALALITE), que é organizada pelo Brasil, Argentina e Chile, completa dez anos congregando pesquisadores de diversos outros países como Alemanha, Bélgica, Espanha, França, Itália, Portugal, Estados Unidos. Também no Reino Unido há iniciativas para a criação de uma associação similar abrigadas em torno do evento Power ofthe Word, capitaneado pela Universidade de Londres ${ }^{2}$.

Esses dados revelam as múltiplas possibilidades de contato entre uma área e outra, e diversas abordagens metodológicas.Nesta primeira décadada existência da ALALITE, por exemplo, muito se discutiu a respeito dos métodos para se trabalhar teologia e literatura. Uma das questões importantes era a de não haver uma relação ancilar da literatura por parte da teologia. Nesse sentido, se entendeu que havia uma unidade sem confusão, de modo que no diálogo com as duas áreas, o teólogo permanece no campo epistemológico da teologia, e de igual maneira o crítico literário, no respectivo campo da literatura. Arrisca-se a dizer aqui, que não é possível pensar um único método, mas sim, uma vez definido o objeto de análise se seleciona a metodologia mais adequada, e mapeia as inúmeras possibilidades daquele recorte investigativo, para delimitar autores, temas, questões implicadas e repercussões de recepção.

Vale ressaltar que o avanço das pesquisas se avalia a partir de seus resultados, e da coerência metodológica, respeitadas as respectivas epistemologias de cada área, sem cair em uma discussão estéril, que daria mais importância a um formalismo em detrimento do sujeito investigativo e seus interesses múltiplos de leitura. A metodologia, portanto, teria como tarefa oferecer um princípio de não contradição e de problematização no diálogo, que ajudasse a melhor explicitar como a literatura ajuda a pensar a questão Deus, ou ainda de modo mais amplo, a questão religiosa.

Neste sentido, a presente proposta de um projeto de pensamento poético teológico compreende que a interlocução da teologia não se dá de maneira fortuita, mas epistemologicamente convergente a partir da categoria da existência religiosa, como sendo outro modo de se falar do que se chama antropologia teológica, dada a convergência epistemológica das duas áreas no dado antropológico. Dentro deste escopo, a categoria por excelência elegida aqui será a do sentido da vida e o como o sentido de Deus se relaciona com a mesma, relação que implica um pensamento poético teológico.

${ }^{2} \mathrm{http}: / /$ www.anselmianum.com/programmi/2015/150617_fil_power_of_the_word/_benvenuti_it_eng.p hp 


\section{A BUSCA DE SENTIDO COMO PATODICÉIA}

A questão do sentido da vida se apresenta com um tema antropológico central, e por isso mesmo, se constitui como ponto de convergência temática entre a centralidade antropológica da literatura e a incidência antropológica de toda afirmação teológica, uma vez que se faz teologia par seres humanos e não angelicais, e nesse sentido se relaciona a questão de Deus e a questão do sentido da vida. Um dos teóricos sobre o assunto, Viktor Frankl (1905 - 1997), criador da logoterapia, fora apontado por dois teólogos de grande envergadura do século XX. O primeiro foi Karl Rahner (1904 - 1984) ao falar da necessidade de uma mistagogia pensada como lógica de conhecimento existencial aponta para a necessidade de diálogo com o autor vienense:

Tal mistagogia que ajudasse a pessoa a se tornar consciente do fato de que essa experiência de transcendência [Transzendenerfahrung] ocorre, repetidamente e sem ser denominada, em seu trato imediato com o mundo concreto, poderia ser possível para cada pessoa em particular somente numa conversa individual, numa logoterapia [Logotherapie] individual (RAHNER, 1984: 68).

Outro teólogo, Bernard Häring (1912 - 1988) também fazia menção a necessidade de dialogar com Frankl para tratar das "doenças noogênicas” da cultura contemporânea como "fonte venenosa" assentada no consumismo, na superficialidade e no culto de ídolos (poder, sucesso, posse, autorrealização individualista). A logoterapia teria a virtude de ajudar a pessoa a "descobrir o próprio sentido da vida", que não pode ser imposto "de fora”, e menos ainda “inventá-lo arbitrariamente", mas "descobrí-lo", porque no fundo se trata da "lei inscrita nos corações", tratando-se do processo de consciência, "favorecido pela solidariedade da procura”, elemento fundamental para uma pedagogia moral em tempos futuros (a saber, pós Concílio Vaticano II), ou seja, um caminhar junto na busca, uma "reciprocidade na procura do sentido mais profundo da vida" e de "soluções responsáveis aos problemas morais da individual e social" (HÄRING, 1991:114-116). Por sua vez, Frankl, não raro recorre a categorias teológicas e a teólogos clássicos e contemporâneos (Tomás de Aquino, Agostinho, Rahner, Tillich...) para melhor elucidar as questões de sentido da vida. Uma de suas categorias fundamentais, por exemplo, a vontade de sentido vista como inscrita na própria existência, é retirada do inquieta cordisde Agostinho. O sentido da vida se inicia como resposta a uma vontade de sentido do qual o ser humano é portador, e vai percorrendo um trajeto do coração à ação responsável por um sentido que vai se configurando com projeto de vida e que o médico filósofo vienense chama de patodiceia (FrAnkL,1978: 243). Tal 
categoria pode ser vista como o processo de subjetivação [pathos] que se torna responsável [diké] à partir de uma experiência de sentido [logos]. O logos, dentro da logoteoria de Frankl é dinâmico e dinamizador do desejo de experiências de sentido que desvelam a essência humana, como modo de ser mais humano, de modo a desalojar da apatia, e oferecer um horizonte de busca dinamizador da existência à partir da vontade de sentido. Na antropologia frankliana, não há uma falta de sentido absoluta, e sim compete ao ser humano descobrí-lo em cada momento. A patodiceiafranklianaacrescenta à leitura freudiana do "desejo de libido", e tal qual a psicodinâmica apresenta a mobilização do desejo diante de um objeto elegido, a existência se mobiliza pela vontade de sentido (1992: 29; 41) diante da descoberta de algo que confira sentido à existência. É exatamente a descoberta de sentido na vida que lhe confere como que um caráter missionário da existência:

O homem é fundamentalmente um ser em busca de um sentido para viver, algo que possa colocar a existência em dinâmica de consumação. Se existe alguma coisa que o possa preservar, mesmo nas mais extremas situações, é a consciência de que a vida tem um sentido, não obstante nem sempre imediato (LUKAS, 2002: 84).

Tal vontade de sentido é que permite ver o homem como capaz de "serconsciente e ser-responsável" e opera como que um chamado de um "Tu", que Frankl atribui a uma presença inconsciente de Deus, não como categoria teológica, mas entendendo Deus como um algo que misteriosamente é involuntário, tal qual o desejo da libido. A vontade de sentido não depende da vontade consciente do indivíduo, mas a solicita, tal qual o cor inquietum agostiniano. Sendo algo que habita no profundo do humano, essa vontade de sentido opera como a categoria Mistério do qual o humano não detém controle, mas antes o interpela, pois não é o humano que faz a pergunta de sentido à vida, mas sim a Vida que o faz. Por isso,

O acesso a Deus [como experiência de Mistério de sentido]só poder ser encontrado a partir do homem. Se tivermos de indicar a outro o caminho que leva a Deus, não podemos tomar por base o racional, mas o emocional" (FRANKL, 2004: 274).

Uma das tarefas fundamentais da logoterapia é ajudar o indivíduo a responder a essa inquietação potencialmente configuradora da existência, ou seja, dinamizar sua própria patodiceia. 
Diante das categorias de Mistério implicado na existência humana e profundidade psíquica apatodiceiafranklinavê na poesia umaforma privilegiada de captar um sentido por proporcionar "vivências interiores e percepções" que vão assim "adquirindo maior intensidade" para apreender os fenômenos essencialmente humanos (PINTOS, 2007: 22s). Ao falar, aqui de poesia enquanto forma de patodiceia, não se trata somente de um "empréstimo de linguagem", mas de um empréstimo de uma forma de pensar, dentro de uma concepção estética no qual a função da forma é manifestar a beleza. Assim se pode entender um pensamento poético, enquanto forma de manifestação crítica da beleza na existência na busca por um sentido verdadeiro. Ou ainda como modo de apreensão de categorias de discernimento para a formação da consciência e da práxis, à partir de um movimento existencial logopático, no qual ocorre um desvelamento de sentido efetivo (logos) porque afetivo (pathos). Rúperez bem descreve o que aqui se propõe, ainda de modo introdutório, por pensamento poético:

É o pensamento que se deriva por um profundo e intenso sentimento ou, mais que o pensamento mesmo, o conhecimento que ele é capaz de gerar (pois todo sentimento profundo é também um profundo ato de conhecimento) [...] $\mathrm{O}$ pensamento que surge em seu interior como consequência das percepções iluminadoras é pensamento poético. O que um poeta pode dizer no interior de um poema como consequência de uma intensa percepção da realidade, seja qual for sua parcela, isso pode ser pensamento poético (RÚPEREZ, 2007: 67-68).

Deste modo, o pensamento poético visa não somente uma aproximação da consciência ao mais verdadeiro, mas uma aproximação que atinja a subjetividade, essencialmente afetiva, pela experiência estética e/oupoética de um texto ou de uma imagem artística e/ou narrativa. Tal forma de pensar visa promover uma recepção perfomativa do sentido textual ou artístico como iconográfico de um sentido existencial, contido na poiésis, como maiêutica do Logos, pois "a verdade subjetiva faz parte da verdade objetiva para se tornar eficaz” (RATZINGER, 2007: 57).

Neste sentido, Frankl assume a influência do pensamento heideggeriano de crítica a uma metafísica que levou ao "esquecimento do ser", e dá atenção a poesia como aquela que melhor cumpriria a finalidade do pensar, coincidindo com o poetar, ou seja, com uma ontologia poética, na qual permitiria o desvelamento da pergunta fundamental ou essencial a um modo de ser específico, a saber o ser humano (HEIDEGGER, 1967: 271). Ademais o místico, no 
sentido heideggeriano, se constitui como um poeta por execelência, por sua tarefa de desvelar o Mistério, elementos esses convergentes em Frankl, ou seja, pensamento poético e pensamento teológico/religioso.Não obstante a crítica de Lévinas (2012), de que os regimes totalitários são possíveis exatamente pelo solipsismo advindo da meditação do Ser, de modo que a tarefa heideggeriana não seria capaz de evitar tal imaginário potencialmente autoritário do Ocidente, não sendo outra coisa a reflexão do filósofo alemão, que mera sofisticação solipsista que continua excluindo o outro da tarefa filosófica, dentro do projeto ontológico Ocidental, Frankl teria, se não as mesmas, ainda razões maiores, enquanto pensador judeu, para acusar Heidegger de filonazismo, tendo sido sobrevivente de três campos de concentração, perdido quase toda a família e a dignidade. Contudo reconhece no pensador alemão, sua amizade e sua influência filosófica para compreender que o "Logos é maior quea lógica". Ademais, é e nesse movimento heideggeriano que a categoria essência dos medievais se desdobra na categoria sentido da vida frankliana, como via possível para se pensar a questão Deus (FrANKL 1978: 273).

É nessa compreensão mais ampla do Logos que a poiésis melhor integra pathose diké, enquanto processo de subjetivação no qual a poesia veicula o acontecimento apropriativoheideggeriano, como um evento ad situationem e ad personam, com um locusrevelationis. Ou seja, um modo de pensar como meio da apropriação existencial das formas poéticas que se desvelam na vida como Mistério, ou ainda, como um excesso de sentido em meio ao absurdo, experiência que o próprio Frankl vivencia como sobrevivente a cinco campos de concentração:

Não preciso de que ninguém me chame a atenção para a condicionalidade do homem: - afinal de contas, eu sou especialista em duas matérias, neurologia e psiquiatria , e nessa qualidade sei muito bem da condicionalidade biopsicológica do homem: acontece, porém, que não sou apenas especialista em duas matérias, sou também, sobrevivente de quatro campos de concentração, e por isso também sei perfeitamente até onde vai a liberdade do homem, que é capaz de se elevar acima de toda a sua condicionalidade e de resistir às mais rigorosas e duras condições e circunstâncias, escorando-se naquela força que costumo denominar de poder de resistência do espírito (2004: 41).

\section{O PENSAMENTO POÉTICO COMO FORMA DE MEDIAÇÃO ENTRE SUJEITO E REALIDADE}

Já Giambattista Vico (1668-1744) como leitor atento de René Descartes (1596-1650) criticava um "cartesianismo linguístico" que passa a ocupar o lugar das humanaelitterae e consequentemente da "sabedoria poética" e mais, da "lógica poética". Neste cartesianismo, a mente humana ao duvidar de tudo o que 
é sensível se fecha sobre si mesma, se apoiando apenas nos encadeamentos dedutivos da lógica, excluindo assim o intercâmbio entre aquilo que se chama de ciência natural e as imagens concretas da vida social, mais precisamente entre linguagem e práxis do cotidiano, e reduzindo assim radicalmente a capacidade que a linguagem literária e artística têm de criar formas de unidade de percepção como núcleo organizador da sociedade e fomentar a vida comunitária, pois propiciam a troca de experiências ao fornece-las imagens que as torne comum, que o filósofo italiano chama de fundo comum de verdade (VICO, 2005, § 144).

Vico pretende combater a hegemônica da lógica cartesiana com a lógica poética, que segundo o mesmo é percebida fundamentalmente por Tomás de Aquino em sua obra De differentia verbi divini et humani na qual a alma humana por haver cogitações, incita o pensamento a discorrer a procura de conhecer a realidade das coisas. Este conhecimento opera em um dinâmica discursiva e processual, e assim sendo, parcial da realidade, ao passo que em Deus há um conhecimento intuitivo, um conhecimento intelectual absoluto que correlaciona verum e factum em uma contemplação [mirandum] da totalidade. A lógica poética deste modo se aproxima do verbum divino, como modo de captar a realidade, de modo sintetizador, ao passo que a lógica abstrata separa e divide, para poder entender a economia das coisas.

A lógicapoéticaviquiana, apresentada em Ciência Nova, opera pela interação entre engenho, memória e fantasia como facetas de uma mesma faculdade que interagem entre mente e corpo, sendo esta a raiz daquela, e, portanto, o sentido se processa a partir dos sentidos, reflexãoe da sensibilidade. A linguagem deriva da sensibilidade corporal em que as coisas imateriais recebem sua significação da realidade material, como por exemplo, "cabeça" para "princípio", "face e costas" para "frente e atrás”, o "tempo fechou” ou o "sol se abriu" para indicar as mudanças climáticas, de modo que a dimensão imagética, tem uma função "icônica" da realidade, permitindo uma compreensão identitária (§ 405-699).

A lógica poética resignifica os dados sensíveis e os reinventa em uma realidade simbólica, em que a memória fornece a recordação sensível do contato físico da realidade, a fantasia altera a imagem da realidade dando ênfases em determinados aspectos significativos formando uma sedimentação de sentido regulada pelo engenho de conformar a imagem à ordem do real, atribuindo um sentido ao mundo fundado e transfigurado em um "universal 
fantástico” (§ 819-852). Tal lógica poética atua de modo hipodigmático, como fundamento dos paradigmas culturais, constituindo-se como uma "tópica sensível” ( $\S 214$ ), transposta na forma imagética, como similitude das inquietações humanas, presente na própria condição humana enquanto "poesia natural".

A tensão criativa da lógica poética está em função de desvelar algum sentido da realidade, sendo ela inclusive doadora do labor do cogito cartesiano, sendo os "universais lógicos" ou "filosóficos" um desdobramento do universal fantástico, porém que incorreram no lapso de colocar a "arbitrariedade do signo linguístico" em primeiro plano, privilegiando a relação entre reset cogito da lógica formal em detrimento da relação res etverba da lógica poética:

Assim, de uma frase poética, por exemplo, "ferve-me o sangue no coração" (que é um falar, por propriedade natural, eterno e universal para todo o gênero humano), do sangue, do ferver e do coração fizeram uma palavra única, como um gênero, que os gregos chamaram stómákhos; os latinos, ira, e os italianos collera $(\S 460)$.

Nesse aspecto a lógica poética de Vico muito se assemelha a psicocrítica de Jacques Lacan (1901-1981) no que diz respeito a primazia do significante sobre o significado, como modo determinante para a relação social. Na perspectiva lacaniana a estrutura social está situada dentro de um Sistema simbólico que abarca toda a realidade material, imaterial e histórica.A estrutura social, portanto, se constitui pela integração do real, do simbólico e do imaginário. A relação social com o outro, por exemplo, nunca é acessada diretamente no real, mas em sua relação com o simbólico e o imaginário, de modo que a relação de alteridade está função da relação consigo mesmo, com os próprios ideais. $\mathrm{O}$ outro é a instância primeira da realidade que solicita do sujeito novas sínteses da realidade, quando o que manifesta não coincide com aquilo que dele é imaginado. Tal produção de sentido para Lacan não é mero exercício racional, mas opera como processo metafórico que inscreve no profundo o "sentido", dentro cadeia de significantes que governa o sujeito (LACAN, 1966: 461). Enquanto o significado como linguagem não é inscrito no imaginário pessoal, comosignificante pessoal, a realidade não existe de modo efetivo.

Nesse aspecto preciso, o universal fantásticode Vico coincide com o imaginário de Lacan e é nesse sentido que as categorias de desvelamento e acontecimentoapropriativo de inspiração heideggeriana ajudam a revisitar a questão de Deus. Ao deslocar a questão teológica de uma metafísica racionalista 
como modo de ser de Deus que serviria de parâmetro para o ser de todas as coisas, inclusive o humano, para o acento na revelação como modo de Deus se dar a conhecer, recupera assim uma lógica poética da Revelação para compreensão deste processo em sua relação com a História. Essa foi a tarefa fundamentalque se dedicou a corrente que ficou conhecida Nouvelle Théologie com seu retorno às fontes de maneira contextual visando uma atualização para o mundo atual, procurando pensar o impacto da religião na sociedade onde está situada na história (MANZATTO, 2016: 9-10). Esta hermenêutica historicizadada Tradição permite uma releitura do imaginário teológico e religioso de cada época como mediação entre o que se chamou de Revelação, expressa como categoria de linguagem simbólica estruturante e a realidade, como espaço da prática cristã. Tal imaginário da Revelação se instala como âmbito cultural emergente da Literatura Bíblica e da Liturgia que doam uma simbólica (1), e portanto, linguagem criadora de um imaginário (2) que opere como princípio de não contradição decorrente de um raciocínio crítico, enquanto tarefa mais sistematizadora daTradição, a fim de esclarecer e propor práticas à comunidade cristã como pertinentes a realidade (3) de seu tempo. Significativa é a expressão da primeira fase do período patrístico, por exemplo, de que o cristão na polis é um politai, um cidadão que assume os problemas sociais como sendo seus (Carta a Diogneto 5,5). Esse período não mais lê a fé cristã como sendo uma seita judaica restrita a Jerusalém ou as sinagogas da diáspora do período anterior, como também não coincide com o período posterior como um habitante do Cristianismo Imperial (VILlas BoAs, 2011: 267-287). Aqui se situa o que é proposto como teopatodiceia como analise e produção de linguagem teológica [théo] que produza um imaginário integrador do processo de subjetivação [pathos] e uma ação responsável e consciente de seu tempo [diké] (VILlas BoAs, 2012), de modo que a forma mentis do pensamento teológico não se restringe a uma questão de significado, mas de apropriação existencial do sentido, que vincula indivíduo e realidade, em uma aliança de compromisso decorrente da própria experiência de fé.

\section{A quESTÃo DE DEUS NO PENSAMENTO POÉTICO COMO METAMORFOSE DO IMAGINÁRIO}

A questão de Deus pensada aqui está situadano espaço que ocupa em imaginário social, na medida em que sustenta uma correlação entre o modo de ver/imaginar a realidade e as práticas sociaisque dão sustentação à organização social. Uma tentação constante das tradições religiosas quando assumem papéis de reguladora social ao serem oficializadas em um âmbito geopolítico é a de 
elaboraram teodiceias que deem sustentação aos regimes teocráticos. Teodiceias são formas de mentalidade religiosa que tendem a substituir as causas históricas por causas divinas, justificando/respondendo (diké) a realidade com causas divinas (theós). Assim fora o caso, por exemplo, da Cristandade enquanto Cristianismo Imperial, pois é próprio das teodiceias substituir causas históricas por causas divinas, e consequentemente substituem a tarefa de patodiceia da cultura de fomentar processos de subjetivação responsáveis, uma vez que o sentido já está dado como vontade de Deus que justifica a realidade de todas as coisas, como forma de blindar o espaço político de seus desmandos.

Contudo, não se trata de um privilégio cristão, mas uma tentação histórica das religiões que passam a exercer uma tarefa normativa na sociedade, como dito acima. Hána teologia homérica, por exemplo, um deslocamento de uma teodiceia na Ilíada para uma forma de teopatodiceia na Odisseia. Para teologia homérica o mito já era visto como resposta aomaravilhoso, uma narrativa fantástica sobre a origem das coisas. Em seu sentido originário o mito não é invenção como fora dito, mas "expressão de verdade" e "revelação do sentido das coisas". O termo indica a concepção de "anuncio" diante da realidade (JEllamo, 2005: 3). Contudo, a forma mentis da mitologia pode mudar no modo de organizar as narrativas dos mitos, como é o caso da teodiceia na Ilíada e de uma teopatodiceia na Odisseia. Há um substrato semântico teológicona Odisseia sob a forma de pensamento poético uma metamorfose das imagens teológicas, como alternativa ao que se considerava uma teodiceia hilemórfica, atuante na forma mentis da população.Essa forma mentis de teodiceia emoldura a mentalidade religiosa que não permite uma indignação moral às formas de autoritarismo e dramas sociais, sendo lidas como vontade dos deuses.

Na Ilíada, o motivo da Guerra de Troia é atribuída a uma disputa de divindades que desejam se vingar da opinião de Paris a respeito da divindade mais bela, ou seja, os motivos históricos da Guerra de Tróia são substituídos por causas divinas, a saber o ciúmes de duas divindades, Hera e Atenas, em detrimento da escolha de Afrodite, como sendo a mais bela entre as três. Essa mentalidade religiosa e cultural sob a forma de teodiceia acentua esse modo de pensar que não permite uma indignação moral às formas de autoritarismo e dramas sociais, uma vez que substitui as causas históricas por causas divinas.

Já na Odisseia, na medida em que Ulisses passa a ter a mediação exclusiva da amizade de Atenas, diferente da Ilíada em que todos os deuses eram adorados para se evitar uma desgraça, há ai uma certa philo-sophia, enquanto 
philo-Atenas já no pensamento poético, enquanto modo de pensar que responsabiliza o indivíduo para consigo e em seu entorno. A mediação exclusiva de Atenas, indica uma mentalidade teológica quepreza pela sabedoria apreendida de uma visão teológica crítica a um imaginário de teodiceia, pois voltar para Ítaca implica enfrentar várias divindades, tal qual a sabedoria da literatura judaica e cristã, que levanta a constante questão de qual Deus é verdadeiro, enquanto pergunta pelo sentido de Deus na busca de sentido humana. Ademais, a Odisseia se acentua a hybris da Casa de Atreu, de onde vêm Menelau e Agamenon no mito de Tântalo, em que a ganância resultaria em sofrimento (Canto XI, 584ss).

A recusa de uma teodiceia resulta na recusa de algumas formas de discurso teológico de alguns mitos, e no modelo de herói que se altera na Odisseia, como aquele que ousa enfrentar as formas de divindade que não coincidem com a justiça [diké], e desmascaram assim a hybris dos homens, enquanto desejo desmedido que se escondem por detrás de formas teológicas. Tal deslocamento semântico da forma mentis dos mitos altera a percepção de herói em Hesíodo. Em o Trabalho e os dias, essa mudança se verifica ao apontar a insuficiência do modelo de rei ou guerreiro para as questões da sociedade agrícola e o problema dos pequenos produtores com os latifundiários. A justiça em Hesíodo se dirige para a necessidade de lutar pela justiça e não pelos desejos confusos da hybris, sendo o trabalhador justo o que deveria ser modelo para a regulação da sociedade. A amizade exclusiva com Atenas, o que configura uma proto-philosophia emergindo da percepção teológica da escola homérica tardia, e a ética como problema filosófico primeiro em Hesíodo, como recusa da espada pela discussão política, moldam a fé na justiça de Ésquilo, como elemento central da crítica dos falsos deuses, que concretamente se materializava no avanço do exército persa, sendo seu imperador visto como a própria divindade.

Há nessa metamorfose teológica a sustentação teórica a democracia a partir do o surgimento do político, enquanto "a arte de decidir por meio da discussão e de obedecer essas decisões como condição necessária para uma existência social civilizada”, bem como a virtude de colocar o poder em comum. Diferente do que afirma Vernant de esse despojar do poder tirânico exigiria "despojá-lo do mistério, arrancá-lo do segredo para convertê-lo em um objeto de pensamento e debate público" e assim apresentar o "caráter propriamente humano" do político, como parte da "consciência de si", vale dizer, portanto, que para Ésquiloa democracia mantém sua relação com a divindade enquanto fé na 
justiça que depõe os falsos deuses, aqueles que manipulam a sensibilidade religiosa para a dominação política(2008: 145).

A questão teológica da teodiceia persiste ainda no imaginário cultural grego sob a categoria destino (moira) e sua força irresistível acima das possibilidades humanas. O problema teológico se dá na medida em que o ser humano está situado entre o destino que se lhe impõe e os deuses que o delineiam em sua vida. Aí se apresenta a pena do poeta na metamorfose de um imaginário teológico que visa desvelar "os motivos ocultos" dessa agência divina. O destino é um castigo dos deuses pela sua hybris. Se em Homero, a hybris se apresenta como o desejo humano de ser como os deuses, e que é ampliado semanticamente como uma desmedida oriunda do orgulho humano que não sabe reconhecer sua condição de mortal, tal desmedida do desejo acaba por ser envolvida em uma cegueira (Ate) que acaba por conduzir a pessoa em uma hamartia, em uma contradição que resulta em um erro fatal, e consequentemente em uma experiência de tragédia. Transposta para a pena do teatrólogo, a tragédia produz o efeito catártico, na medida em que aquilo que afeta o herói, também afeta o espectador, e assim identifica o destino do herói como uma possibilidade para própria vida do espectador. Esse é "o mistério da dor enviada pelos deuses à vida dos homens" (JAEGER, 2013: 298-301).

Nesse sentido, a hybrisda tragédia esquilianaestá na base antropológica dapleonexia social enquanto desejo insaciável de possuir o dobro do que tem, sendo fonte de injustiça e posse material do que pertence a outrem. A consciência trágica emerge quando "a linguagem do mito deixa de apreender a realidade política da cidade" (VERNANT; VIDAL-NAQUET, 2013, prólogo: 1s), sendo assim a teologia da tragédia esquilianauma revisão do imaginário dos mitos na medida em que não mais moldam personalidades justas. $\mathrm{O}$ ponto de partida da tragédia esquiliana, portanto, se dá na primeira peça, Os persas, em que não há presença do elemento mítico, mas um acontecimento histórico sob forma de tragédia, a saber as guerras de resistência à invasão dos persas. Ali o poeta não se limita a mera dramatização da história, mas visa penetrar no orgulho dos tiranos (hybris), causa da catástrofe persa, por se utilizar de uma legitimação teológica para injustiça, sendo então a queda humana o evento em que o governo divino melhor se manifesta. Destarte, o desejo insaciável de dominação persa (hybris) que impulsiona a tentativa de conquista das terras gregas (pleonexia) é a própria causa de condução a cegueira (Ate) e consequentemente à derrota. Mais precisamente, a hybris de Xerxes I, que em nada lembra a sabedoria do antigo rei persa, Dario, invocado na peça, inclusive: 
A soberbia (hybris), ao florescer, produz a espiga

de erronia (Ates), cuja safra toda será de lágrimas.

Quando estes [os persas] se veem assim punidos,

lembrai-vos de Atenas e Grécia; ninguém,

por desprezo ao seu presente Nume (daimon),

por querer outros (pleonexia), verta grande opulência.

Zeus punitivo vigia os demasiado

soberbos pensamentos, severo juiz.

Portanto, com bons conselhos inspirai

àquele carente de prudência (sofronein) que cesse

de ofender a Deus com soberba audácia (Os persas, v. 821-831).

Para Jaeger "tudo o que acontece na tragédia encontra-se sob a preocupação dominante do problema teológico" (2013: 301), e a tragédia esquiliana abordará o problema da hybriscomo um pecado de origem que se manifesta na desmedida enquanto desejo excessivo que resulta em injustiça social, revisitando o oráculo délfico, ao propor que pela dor o homem também deve conhecer a si mesmo, sendo Dioniso a divindade que irá propor o desafio do enigma de si, e suas consequências sociais, a divindade que representa a alteridade.

Se para o pensamento mítico "a experiência cotidiana se esclarecia e adquiria sentido em relação aos atos exemplares praticados pelos deuses" na origem de tudo, por outro lado, eles são concebidos como "mitos de soberania" nos quais a "hierarquia social" ganha uma ordem divina, pois os mitos não questionam como o cosmos surgiu do caos, mas "quem conseguiu reinar (anassein, basileuein) sobre o universo" (VERNANT, 1998: 81-93). Tal imaginário é radicalmente distante da democracia ática, em sua luta pela justiça (diké) contra a desmedida gananciosa (hybris). Aí se constata a influência de Hesíodo em Ésquilo que irrompe contra esse imaginário que o herói mítico reforça. A teologia esquiliana elege uma divindade marginal da epopeia, pois Dionísio não representa o "domínio de si", a "moderação", a "consciência de seus limites", mas encarna "a busca de uma loucura divina", um "desterro radical de si mesmo", sendo este arroubo de si, o questionamento às cegueiras que residem não somente entre os persas, mas entre o próprio gênero humano, inclusive os gregos.

A democracia exige uma nova leitura dos valores que passaram a servir para a manutenção da ordem dabasileia, o que supõe uma metamorfose teológica para dar visibilidade à cegueira da mentalidade que não corrobora com a mudança da época, na medida em que a cidade é posta nos palcos, e Dioniso servirá de inspiração para misturar "as fronteiras do ilusório e do real" 
(VERNANT; VIDAL-NAQUET, 2013: 161-162), fazendo submergir bruscamente o Mistério que escapa ao controle dos homens.

Os mitos passam, portanto, a acoplar um papel estético, para além do ritual, de modo que a representação do mito na tragédia tem a função de atingir a profundida da percepção do espectador, ao usar a mediação do símbolo mítico para penetrar no espírito, "no que a pessoa tem de mais profundo" (JAEGER, 2013: 298), a partir das lendas gregas que a epopeia tornara familiar a cada grego (VERNANT; VIDAL-NAQUET, 2013: 158). A categoria teológica, por excelência, de Ésquilo é a apataTheou ou o engano de Deus, ou ainda o logro divino, como prefere Torrano (2009: 37-43):

Do fraudulento logro de Deus (apátantheou) que homem mortal há de escapar?

Quem com rápido pé salta um salto bem dado? (Os persas, v. 93-96)

Tal capacidade divina de enganar se manifesta na medida em que o homem se deixa conduzir pela sua hybris, ou seja, a obstinação que leva a reduzir o outro e tudo o mais a seus propósitos. Nesse instante o engano de Deus opera na forma do daimon homérico da Ate, que em Ésquilo sofre uma ambiguidade em que ora diz respeito à ação humana, ora a manifestação divina. Enquanto ação humana, se manifesta como cegueira oriunda da obstinação do desejo desmedido, comportamento permitido somente aos deusesilidíacos. Por outro lado, enquanto manifestação dionisíaca é uma força irresistível, que "não há como evitar nem fugir" e que conduz esse desejo insaciável que vai sendo alimentado à seu termo. Então se desvela na ruína as consequências que a cegueira da obstinação não permitia enxergar. Assim se dá a conhecer a justiça divina enquanto a iniciativa humana é enredada na "erronia" (Ate) e se revela a forma divina na situação ruinosa.

\section{A MORTE DE DEUS COMO ASCENSÃO DA TEODICEIA LEIBNIZIANA}

Quando o Zaratustra de Friedrich Nietzsche (1844-1900), enfastiado de sua sabedoria, desce da montanha para anuncia-lá aos demais e assim voltar a "tornar-se humano", é indagado no caminho a respeito de sua intenção, por um santo que segue em sentido contrário, ao que responde: “Amo os homens”. E tal santo lhe retruca:

Pois por que - disse o santo - vim eu para a solidão? Não foi por amar demasiadamente os homens? Agora amo a Deus; não amo os homens. O homem 
é para mim, coisa sobremaneira incompleta. O amor pelo homem matar-me-ia (NIETZSCHE, 2009: 06).

Nesta controversa questão da morte de Deus a principal questão para a teologia moderna, sentida na sua forma mais cruel e que marcou toda uma época se localiza na questão de como o amor a Deus leva à apatia pelos homens. Na antiga cosmovisão do Cristianismo Imperial, Deus era o personagem mais importante para sua compreensão, e por sua formulação metafísica, de matriz platônica substituía os deuses gregos e fundamentava com isso um sentido de sociedade e de vida. As contradições dessa sociedade e a tentativa de sustentá-la em nome de Deus acabaram por debilitá-lo até a morte. Para Jaspers, o Deus que morre em Nietzche é vitimado pelos cristãos (1955: 24-25) eVattimo vai mais além e diz que é a religiosidade dos cristãos (2009: 38-39). A morte de Deus coincide com o "fim" de uma certa metafísica, sobretudo da escolástica tardia, que dava sustentação a um modo de sociedade. O que Nietzsche está chamando de "morte de Deus" é possível ser lido como recusa da teodiceia leibniziana, tal qual a recusa da escola homérica tardia da Odisseia (LEIBNIZ, 1995: 6).

A teodiceia, deste modo, substitui o imaginário de uma patodiceia, transferindo a resposta existencial a Deus, cristalizando uma figura teológica que subverte a consciência de justiça em lógica justificativa da tragédia, e até mesmo na justificativa da injustiça como vontade de Deus. Se a patodiceia se pauta por um saber que provoca o questionamento, a teodiceia sustenta o status quo, primeiramente de si, e se estende a seu meio, anestesiando a necessidade do indivíduo de responder [diké] aos fatos que se lhe impõe, afetando-o [pathos] na vida concreta, exigindo dele a elaboração de um pensar adequado [logos], e deste modo, a teodiceia é a responsável cultural pela apatia social na transição do mundo antigo para o mundo moderno, permanecendo no imaginário como reminiscência imperial.

Na medida em que para Nietzsche a realidade humana é percebida pela tragédia, ou ainda pelo modo como os gregos a elaboravam, isto é, pela reinvenção poética e/ ou artística da vida diante do sofrimento, que com os olhos da arte se pode mergulhar no coração do mundo, retoma a pauta da substituição da teodiceia por uma recuperação da patodiceia. O pensamento trágico tem como característica o sofrimento proveniente da paixão de viver e provoca uma resposta à vida concreta (NIETZSCHE, 2006: 27-31). A recusa da teodiceia é que permite reinaugurar a patodiceia da existência considerando a 
angústia como solicitação de um sentido que personalize a existência. A patodiceiapode ser entendida como busca de algo pelo qual a vida se dê em consumação, de modo que co-responda à sua vontade de sentido apesar absurdo de existir.

Em Frankl, como leitor de Nietzsche, não necessariamente a vida faz sentido, mas sim que o absurdo da existência não é absoluto, e a vontade de sentido anseia por descobrir aquilo pelo qual a vida passa a valer a pena de ser vivida.Nesse aspecto, o que se chama aqui de pensamento poético visa despertar não somente uma inteligência do sentido, mas, sobretudo a vontade de sentido, origem de sua busca que resulta na responsabilidade existencial e na liberdade livre para decidir-se pelo que dá sentido apesar de todos os condicionamentos, pela identificação com uma imagem significativa que vem ao encontro da busca.Assim, a poesia é um modo privilegiado de patodiceia, por ser a poesia noodinâmica, em seu movimento do texto à ação, como capacidade de responder aos apelos da existência:

Não perguntamos mais pelo sentido da vida, mas nos experimentamos a nós mesmos como os indagados, como aqueles aos quais a vida dirige perguntas diariamente e a cada hora perguntas que precisamos responder, dando a resposta adequada não através de elucubrações ou discursos, mas apenas através da ação, através da conduta correta. Em última análise, viver não significa outra coisa que arcar com a responsabilidade de responder adequadamente às perguntas da vida, pelo cumprimento das tarefas colocadas pela vida a cada indivíduo, pelo cumprimento da exigência do momento (FRANKL, 2005: 48).

É inerente ao pensamento poético serlogopático na medida em que traduz osanseios humanos e seu desejo de ir além de si. O übermensch nietzschiano é relido em Frankl como um metahumano, ou seja, como humano do humano, e ainda aquilo que dá sentido ao humano, o Logos. Há uma perspectiva apofática da metafísica, um reconhecer do Mistério como excesso de sentido que sobrepõe à condição de absurdo da existência. A questão de Deus em Frankl não se revela, mas está na condição de permitir uma descoberta de sentido sob o véu de um mistério. Deus aqui está ligado ao mistério da vida que é capaz de se refazer e se revelar como prenhe de sentido, dentro de um eterno retorno na tensão de Apolo e Dionísio, entre a descoberta de sentido e o sentido que se esvai. Deus é visto como o Mistério da possibilidade de sentido da vida, apesar do absurdo.

Para a logoteoria, a literatura em "seu poder de penetração é admirável" e exerce um efeito catalisador para a busca de sentido "efetivo", pois sua mensagem chega de "surpresa" e "mobiliza no indivíduo seu poder de resistência" e o "que resta de são" para a superação das adversidades. A leitura 
da literatura vai introduzindo o indivíduo em "estado de meditação", a fim de "dar algum nome" às "vivências interiores e percepções", que vão assim "adquirindo maior intensidade" de sentido na medida em que se identifica intelectual e emocionalmente com o movimento da poiésisdo texto literário, incorporando-o. Deste modo apoiésisé capaz de "operacionalizar os fundamentos filosóficos" (PINTOS, 2007:21-22; 43), e assim se configura como um pensamento poético.

\section{A RECUPERAÇÃO DA LÓGICA POÉTICA DA REVELAÇÃO}

O que se apresenta aqui como próprio do diálogo entre Teologia e Literatura é a identificação da crise da linguagem teológica que suscita a tarefa de refeitura da questão de Deus no imaginário cultural, especialmente como superação das formas de teodiceia, que resultam ora em apatia, ora em fundamentalismo ativista, sendo ambos causa de danos sociais e pessoais. Na proposta de uma teopatodicea, Deus não é visto como em uma teodiceia, mas como participante da patodiceiahumana, como uma presença misteriosa e desconhecida que se faz perceber como uma força de sentido quando o sentido se esvai, como que atuando em causas segundas que insistem com o humano (RAHNER, 1984: 93-96). Nesse aspecto, na medida em que o pensamento poético é essencial para a patodiceia, se pensa aqui em um pensamento poético teológico, no qual o sentido de Deus seja reafirmação do humano, ressignificadasas tradições para a tarefa de humanizar o humano.

Também aqui fica a tarefa superação da morte de Deus como more ou superação da teodiceia moderna em diálogo com a literatura, pois arecusa ou a não recepção de Deus na literatura se deu como destruição poética da teodiceia em nome de uma sensibilidade ética de época que foi sendo cunhada como alteridade dentro do horizonte de expectativas do indivíduo moderno, tal qual a refeitura do imaginário teológico na cultura grega. A Estética da Recepção, de Jauss, por exemplo, já havia apontado que a forma de pensar que desconsidera a subjetividade, ou seja, sensibilidade do outro, é no mínimo, potencialmente autoritária e engendra no imaginário social a possibilidade de formas de autoritarismo, e o consequente não reconhecimento da alteridade e do conflito como dimensões fundamentais da existência. A literatura nesse sentido colabora como depuradora moral provocando a repensar as formas históricas de cristandade reminiscentes na mentalidade cristã. $\mathrm{O}$ reconhecimento da crítica literário-histórico-social tem um efeito redentor no horizonte de expectativas do 
indivíduo afetado por formas de apatia institucional, ao mesmo tempo em que reforçar um otimismo estético, reforça a não-recepção do discurso teológico.

Nesse sentido a questão de Deus não é suficiente apenas como sofisticação estética da argumentação teológica, mas deve comportar uma poética da realidade e da alteridade como capacidade de despertar para a sensibilidade do outro, no qual Deus seja esse elemento de desalienação e abertura, dentro da tarefa da morte da teodiceia. Nesse aspecto vale analisar dois projetos teológicos que enfrentam o problema da linguagem teológica.

\subsection{A ESTÉTICA TEOLÓGICA DE HANS URS VON BALTHASAR}

Hans Urs von Balthasarem seu projeto de Estética Teológica faz uso em larga escala da Literatura germânica, especialmente de Goeth, criticando o racionalismo advindo dos debates dogmáticos da Antiguidade Cristã que reultaram em uma“precisão do âmbito conceitual”, em detrimento da imagem, uma vez que "o conteúdo dos sentidos e a fantasia dão a conhecer de forma imprecisa e perifrástica”, carecendo assimda "dinâmica erótica” da imagética, que "cai necessariamente em cartesianismo, idealismo ematematecismo"(BALTHASAR, 1985: 125-126). Na teologia fundamental balthasariana a estética se constitui como doutrina da percepção da forma de Deus para formular uma "razão estética" como "razão contemplativa cristã", que visa à percepção da manifestação divina. Remete, portanto, a noção de Gestalt ou figura que é uma manifestação da beleza pela qual configura (Gestalt) a existência ao Ser. Na fenomenologia balthasariana a figura aparecente [Erscheinende Gestalt] só é bela porque há uma complacência [Wohlgefallen] com aquilo que não somente se dá a mostrar [Sich-Zeigen] mas também se doa [Sich-Schenken] nessa manifestação. A beleza da figura se dá na profundidade da verdade e bondade da realidade que se manifesta como algo inesgotavelmente precioso e fascinante. Compete a estética teológica, portanto, promover uma consciência metanoética, reintegrando epistemologia e metafísica, entendida como ontologia. Assim, o primeiro ponto de partida de uma metafísica, como pergunta pelo "fundamento inerente e sentido" do Ser, diz respeito ao modo como conhecer. Por isso, para que a figura seja recebida como manifestação da beleza divina, há que se ter uma inteligência teologal da figura, por meio de uma justa interpretação, de dupla evidência, objetiva, em que Deus está patente entre os homens e subjetiva, pela factibilidade da consciência de reconhecer a aparência mesma de Deus. É na subjetividade que a fé tem olhos para perceber o que foi posto a luz, então a noção de figura se 
multiplica e diversifica como figura espiritual, figura de vida, de beleza, do verdadeiro e do bom. Ela sempre remete a figura arquetípica de Cristo,única figura que pode alcançar a totalidade gloriosa. Afigura crísticaé a visibilidade de Deus que traz uma nova forma de visibilidade e aí se funda a teologia dogmática como doutrina do arrebatamento e extâse. Contudo na perspectiva balthasariana, a Gestalt do amor trinitário reside nessa obediência da Cruz. Há uma "dialética da cruz", de reconhecer na contemplação da cruz o merecimento da condenação própria como "assassino do amor eterno" e ao mesmo tempo, a morte vicária de Cristo pro me convida ao seguimento como obediência. Tal movimento dialético é visto pelo teólogo suíço como "núcleo da tradição autenticamente católica" (2009: 180-181). Ademais, a figura crística não se revela em sua compreensibilidade, pois, se comprehendis non est Deus, mas sim em sua credibilidade, pois a estética crística como obra de arte, quanto mais se compreende algo dela, tanto mais brilha sua "incompreensível genialidade". Nessa perspectiva é que a misericórdia de Deus se manifesta na beleza da Cruz, por mais terrível que ela seja, a obediência do Filho por amor aos filhos de Deus, compõe a Gestalt do arrependimento e início da disposição interior (BALTHASAR, 1985a: 171; 486).

\subsection{A POIÉSIS COMO ESCOLA DE ESCUTA EM KARL RAHNER}

Em Karl Rahner a questão da poiéisem Rahner, por sua vez, participa da sua compreensão de Revelação como autocomunicação de Deus enquanto recepção existencial de uma experiência produtora de sentido que tem na pessoa de Jesus Cristo sua "forma originária" (Urform) (RAHNER, 1965: 100) de "receptor" e "clímax", e não pode ser conhecido apenas por "teoria dogmática imposta ao ser humano desde fora". Assim Jesus Cristo é a "Palavra abreviada de Deus" uma "cifra do próprio Deus" e do próprio ser humano por toda eternidade, dada sua densidade de sentido (excessus), em sua realidade teândrica, e em consequência disso, "toda teologia continua sendo antropologia por toda a eternidade", a "unidade da pergunta surgida historicamente (que é o ser humano) e da resposta (que é Deus)". Deste modo, a "cristologia constitui o começo e o fim da antropologia em sua mais radical realização é, por toda a eternidade, teologia" de modo que então só pode ser conhecido em uma "experiência transcendental" ou seja, em uma "cristologia transcendental" como graça. O conhecimento de Cristo se dá como identificação existencial com a pessoa de Jesus Cristo como um “mudar-se-no-outro" (RAHNER, 1984: 147-270) que ao "afetar" existência chama a liberdade para Sua poiésis como caminho de "realização existencial” (RAHNER, 1965: 117). 
Em Rahner, portanto, poesia e humanidade são sinônimos, uma vez que a poesia é radicalmente humana, e o ser humano potencialmente, ou ainda aprioristicamente poético, como alguém em busca de sentido ou ainda como ouvinte da Palavra. Portanto, tal Palavra de Deus não é outra coisa senão Palavra poética [Das Wort der Dicthung] que desvenda as inquietações da vontade de sentido, pois só ela tem o poder de nomear o inexprimível. Para Rahner essa inquietação é o efeito da presença do Espírito e se pode chamar em sentidoestrito que a "palavra da Escritura" contém a "palavra poética”, de modo que "a capacidade e o exercício, de perceber a palavra poética é um pressuposto para, ouvir a Palavra de Deus" (RAHNER, 1962: 441- 448). Aliás, se há um pressuposto, enquanto preparação para ser cristão é a "generosacapacidade de recepção da palavra poética":

De qual palavra, portanto, deve o cristão ter sido capacitado para ouvir, ter sido treinado e agraciado, para poder ouvir a palavra cristã da mensagem de Deus? Ele precisa poder ouvir a Palavra, através da qual o mistério silencioso se faz presença, precisa poder perceber a Palavra, a qual atinge o mais íntimo de seu coração, ele precisa estar iniciado na graça humana de ouvir a palavra unificadora que integra e que no meio de sua clara finitude mesma esta o mistério infinito em sua corporeidade. Mas como se chama essa palavra? Essa palavra é a palavra poética; Esse poder de ouvir é auscultado da palavra poética, sobre a qual o ser humano em humilde disposição se envolve até que se abram os ouvidos do espírito e por ele lhe penetrem no coração (RAHNER, 1962: 441).

Para o autor a poesia é uma condição sinequa non para a teologia, pois se "essa capacidade essencial do coração fosse realmente desaparecida, o ser humano não poderia mais ouvir a Palavra de Deus na palavra humana”.Ao falar da poesia como pressuposto não se trata de uma mera preparação para o Evangelho de modo ancilar, mas deve ser lido em referência as exigências da mudança de época do cristão do futuro em que o pensamento poético diz respeito à própria natureza da mística, porque "somente é autêntica poesia lá, onde o ser humano se depara radicalmente com o que é ele mesmo". Deste modo "o autêntico cristianismo e a autêntica poesia possuem uma afinidade íntima”, expressões do Espírito que age no mundo (RAHNER, 1962:449-451).

\section{CONCLUSÃO}

O diálogo entre teologia e literatura nomeado como teopoética assumiu muitas formas. A presente proposta de formular um pensamento poético teológico é apenas uma entre tantas, e se dirige a tarefa fundamental de pensar o imaginário de Deus na cultura e como isso interfere nas sensibilidades e práticas do tempo atual. Por pensamento poético teológico procura-se 
apresentar como a dinâmica da Revelação de Deus, dentro da tradição teológica, comporta uma lógica poética, enquanto desvelar a Revelação em um dinâmica poética coincide com a humanização do humano, e não somente em apresentar uma apreciação estética de Deus. Essa recuperação da lógica poética se propicia, de modo especial, a recuperar a relação existencial do Cristianismo como paideia alternativa, que aqui nomeou-se de teopatodiceia, enquanto apropriação existencial e social das formas poéticas,religiosas ou não, que auxiliem um imaginário capaz de dinamizar processos de subjetivação abertos a alteridade, e com responsabilidade por um projeto de vida e compromisso social.

A substituição de patodiceias por teodiceias é uma tentação comum às teocracias que visam oferecer um imaginário teológico em que as causas históricas são substituídas por causas divinas. A superação de um teodiceia supõe, como aqui se propõe, a elaboração de uma teopatodiceia enquanto reelaboração da imagem de Deus (Theós) a fim de reafirmar a condição humana. Tal processo pode ser identificado no deslocamento semântico teológico da teologia homérica, da Ilíada para a Odisseia, que por sua vez influência a questão antropológico-teológica em Hesíodo e Ésquilo, recuperando a dimensão histórica e trágica da cultura, crítica essa que conduz Nietzsche em sua crítica ao Cristianismo e a perda da consciência trágica.

Nesse sentido um imaginário teológico que não ajude a pensar/imaginar Deus a dinâmica do conflito incorre em reforçar, ainda que de modo não intencional, esse imaginário de teodiceia, que anestesia a noção de conflito e com isso a necessidade de transformação histórica. Entretanto, a questão deve ser vista dentro do imaginário teológico e religioso da cultura e que práticas fomentam em sua recepção. Se a beleza é um elemento fundamental da questão de Deus, há que se perguntar que imagem de beleza se apresente e qual sua repercussão na recepção do imaginário teológico da cultura, $\mathrm{Na}$ cristologia presente na Teodramática de Balthasar há uma perspectiva descendente, e, portanto, uma perspectiva "de cima" que enfoca a beleza do amor de Deus que sofre junto com seu Filho, perspectiva essa que influencia a teologia política européia enquanto despe Deus da apathiké da metafísica aristotélica, e reveste a práxis em uma analogia da compaixão. Entretanto o enfoque dado ao drama cristológico é atenuado na perspectiva balthasariana, mantendo o movimento da perspectiva de cima, enfocando que sobre a "Cruz de Cristo" está exposto o "Amor do Pai". Pouco, se evoca, entretanto, a experiência do"terrível" da cruz, ainda que se saiba da proximidade do Pai, na dimensão antropológica, pois, enquanto perspectiva ascendente, do humano a 
Deus, a experiência é de "abandono por parte de Deus"(RAHNER, 1965: 222223). Essa postura rahneriana corresponde a de "recusar o otimismo", para a escuta de um"radical realismo" [radikaleRealismus] como melhor "testemunho da verdade". A "utopia de que um mundo funcionando em perfeita harmonia possa vir a ser criado pelo próprio homem inevitavelmente conduz a violência e crueldade maiores do que as que o homem quer banir do mundo". O otimismo que alimenta alguma forma de romantismo "quer idealista, quer comunista", é um "ópio para o povo" [Opiumdesvolkes], quanto à "situação de liberdade" que o ser humano se encontra"(RAHNER, 1984: 116), pois a vida não faz sentido de per si. E por isso "a poesia é necessária” porque "a poesia tem que falar do concreto" (RAHNER, 1962a: 450-452) e por isso se torna um "acontecimento" que permite encontrar o sentido da sua própria situação da vida apropriado sobretudo para o otimismo trágico de Frankl, de modo a ajudar a atravessar "o inferno da desesperança" da aparente "carência de sentido". Ali então na concretude da existência, diante da tarefa constante de responder a vida com as atitudes, e a poesia, enquanto escuta e dizer poético, pode ajudar a encontrar a revelação napráxis (METZ, 1999: 246-255).

Destarte, a noção de estética de Hans Robert Jauss, ao ser entendida preferencialmentecomo "sensibilidade", abrange a questão da "alteridade" ede seu "horizonte de expectativa" (1989: 112-128), pelo qual se apreende uma identidade a partir da experiênciaestética, mas também por uma noção intersubjetiva, no qual a literatura, por meio da imaginação literária provocaa Historia geral a uma mudança social como traço da personalidadesubjetiva. A recepção estética de uma obra acontece pelo seu "grau de verdade", como "emque medida reconhecemos nela alguma coisa, nos conhecemos e nos reconhecemosnela". Tal verdade pode ser tanto prazerosa e desveladora depossibilidades como também uma "frustração de expectativas", semelhantea "experiência de um cego que choca com um obstáculo e apreende assima sua existência", ao entrar "verdadeiramente em contato" com a "realidade", funcionando como"sentido criador da experiência negativa a práxis da vida", conduzindo a“renovar” a “percepção das coisas”(2003: 109).

Na história da recepção estética da teologia aos moldes balthasarianos, ao menos no cenário da teologia brasileira, acaba por ser recebida como essencialista por seu método de transcendência, e isso soa ao menos como insuficiente para transformação de realidades históricas. Todo discurso essencialista, para Jauss, seja religioso, marxista, formalista, ou o arquetipismo das novas críticas não provoca a História a partir de sua base, ou seja, o 
indivíduo receptor, mas antes causa uma percepção anestesiada da realidade, por viver na prática o que rejeita na teoria. Nesse sentido, para Jauss não é somente o prazer, ou o fascínio para lembrar Balthasar, que conduz a mudança, mas também a frustração oriunda da experiência estética e que permite perceber o equívoco da própria percepção de contradição, somente alcançada pela análise histórica. Ao passo que a dimensão rahneriana da antropologia teológica identifica a "beleza" na superação do conflito, o que implica antes, escutá-lo, sendo a poesia essa escola de escuta do mais profundo e mais concreto. A lógica poética da Revelação se dá muito mais nesse desvelamento de sentido e transcendência diante da superação da finitude, reconciliação do encontro e abertura aos desafios de fronteira do que na concepção de uma harmonização do conflito sob uma estética da cruz, que incorre no risco de retroalimentar um imaginário de teodiceia, ao invés de uma sensibilidade à presença do Mistério na dinamização interior da busca de sentido e processos de subjetivação responsável.

\section{REFERÊNCIAS}

BALTHASAR, H. U. v.Textos de EjercíciosEspirituales. Selección e introducción por Jacques Servais. Col. Manresa. Bilbao: EdicionesMensajero/Santander: Ediciones Sal Terrae, 2009.

BALTHASAR, H. U. Gloria: Una Estética Teológica. Vol. 1: La Percepción de la Forma. Madrid: Ediciones Encuentro, 1985.

BALTHASAR, H. U. Gloria: Una Estética Teológica. Vol. 2: Estilos Eclesiásticos. Madrid: Ed. Encuentro, 1986.

CANTARELA, A. G. Modelos de Leitura do diálogo entre Reiligião e Literatura. In Anais do V Congresso da ANPTECRE "Religião, Direitos Humanos e Laicidade". PUC PR: Curitiba, 2015: 107-114.

ÉSQUILO. Tragédias. Edição bilíngue. Estudo e Tradução JaaTorrano. São Paulo: FAPESP/Iluminuras, 2009.

FRANKL, V. A Presença Ignorada de Deus. $8^{\text {a }}$ ed. São Leopoldo: Editora Sinodal; Petrópolis: Editora Vozes, 2004. (Coleção Logoterapia).

FRANKL, V.Em Busca de Sentido: Um Psicólogo No Campo de Concentração. $21^{\mathrm{a}}$ ed. São Leopoldo: Editora Sinodal; Petrópolis: Editora Vozes, 2005. (Coleção Logoterapia).

FRANKL, V. Fundamentos Antropológicos da Psicoterapia. Rio de Janeiro: Zahar Editores, 1978.

FRANKL, V.Psicoterapia Y Humanismo: Tiene Un Sentido La Vida. México: Fondo de Cultura Económica, 1992. 
HÄRING, B. Teologia Moral para o Terceiro Milênio. Edições Paulinas: São Paulo, 1991.

JAEGER, W. Paideia: a formação do homem grego. São Paulo: Martins Fontes, 2013.

JASPERS, Karl. Nietzsche y el Cristianismo. Buenos Aires: Editorial Deucalión, 1955 .

JAUSS, H. R. HistoriacalamitatumetfortunarummearumIn COHEN, Ralph. (ed.) The Future of Literary Theory. New York: Roudedge, 1989: 112-128.

JAUSS, H. R.Literatura como Provocação: História da Literatura como provocação literária. Lisboa: Veja/Passagens, 2003.

JELLAMO, A. Il caminho didiké: L’ideia de giustizia da Omero a Eschilo. Roma: Donzelli Editore, 2005.

LACAN, J. Situation de lapsychanalyseen 1956 In Écrits. Paris: Seuil, 1966.

LEIBNIZ, Gottfried Wilhelm.Discurso de metafísica. Lisboa: Colibri, 1995. (Universalia. SérieIdeias).

LEVINAS, E. Humanismo do Outro Homem. Petrópolis: Editora Vozes, 2012.

LUKAS, E.. Psicologia Espiritual. São Paulo: Paulus, 2002. (Coleção Psicologia Prática).

MANZATTO, A. O Vaticano II e a inserção de categorias históricas na teologia In Cadernos de Teologia Pública, Ano XIII, vol. 13, n. 107. São Leopoldo: Instituto Humanitas, 2016.

METZ, J. B. La foi dans l'histoire et dans la société: Essai d'une Théologie Fondamentale Pratique. Col. CogitatioFidei, n. 99. Paris: Cerf, 1999.

NIETZSCHE, F. Also Sprach Zaratustra: Ein Buch für Alle und Keinen. Norderstedt: GRIN Verlag, 2009.

NIETZSCHE, F. Die Geburt der Tragödie aus dem Geiste der Musik. Teddington: Echo Library, 2006.

PINTOS, C. G. Logoterapia em Contos: O livro com recurso terapêutico. São Paulo: Paulus, 2007.

RAHNER, K. Das Wort der Dichtungund der Christ In SchriftenzurTheologie: Band IV - NeuereSchriften. Zürich/Köln: BenzingerVerlagEinsiedeln, 1962: 441-454

RAHNER, K.Betrachtungen zum ignatianischen Exerzitienbuch. Münschen: Kösel, 1965.

RAHNER, K. Grundkurs des Glaubens: Einführung in den Begriff des Christentums. Freiburg-Basel: Herder, 1984.

RATZINGER, Joseph. Dogma e Anúncio. São Paulo: Edições Loyola, 2007.

RÚPEREZ, Ángel. Sentimiento y Creación: Indagación sobre elorigen de la literatura. Madrid: Editorial Trotta, 2007.

VATTIMO, Gianni. Después de lacristiandad: por un cristianismo no religioso. Buenos Aires: Paidós, 2009.

VERNANT, J-P. As origens do pensamento grego. $10^{\text {a }}$ edição. Rio de Janeiro: Bertrand Brasil, 1998. 
VERNANT, J-P. Atravesarfronteras: Entre mito y política. Col. Filosofía, n. 11. Buenos Aires: Fondo de Cultura Económica, 2008.

VICO, Giambattista. A Ciência Nova. Lisboa, Fundação CalousteGulbenbenkian, 2005 .

VILLAS BOAS, Alex. Entre a Teografia e a Teologia In FERREIRA, A. M. (org). Teografias - Sentimento Religioso e Cosmovisão Literária. Aveiro: Universidade de Aveiro, 2011: 267-287

VILLAS BOAS, Alex. Teologia e Literatura como Teopatodiceia: em busca de um pensamento poético teológico. 2012. Tese (Doutorado) - Pontifícia Universidade Católica do Rio de Janeiro, Programa de Pós-graduação em Teologia, Rio de Janeiro.

Recebido em 24/o4/2016 Aprovado em 03/06/2016 